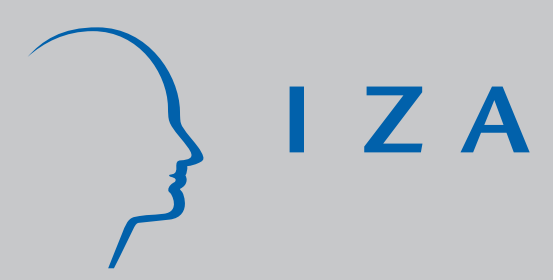

IZA DP No. 5869

Life Satisfaction and Grandparenthood:

Evidence from a Nationwide Survey

Nattavudh Powdthavee

July 2011

Forschungsinstitut

zur Zukunft der Arbeit

Institute for the Study

of Labor 


\title{
Life Satisfaction and Grandparenthood: Evidence from a Nationwide Survey
}

\author{
Nattavudh Powdthavee \\ Nanyang Technological University \\ and IZA
}

Discussion Paper No. 5869

July 2011

IZA

P.O. Box 7240

53072 Bonn

Germany

Phone: +49-228-3894-0

Fax: +49-228-3894-180

E-mail: iza@iza.org

Any opinions expressed here are those of the author(s) and not those of IZA. Research published in this series may include views on policy, but the institute itself takes no institutional policy positions.

The Institute for the Study of Labor (IZA) in Bonn is a local and virtual international research center and a place of communication between science, politics and business. IZA is an independent nonprofit organization supported by Deutsche Post Foundation. The center is associated with the University of Bonn and offers a stimulating research environment through its international network, workshops and conferences, data service, project support, research visits and doctoral program. IZA engages in (i) original and internationally competitive research in all fields of labor economics, (ii) development of policy concepts, and (iii) dissemination of research results and concepts to the interested public.

IZA Discussion Papers often represent preliminary work and are circulated to encourage discussion. Citation of such a paper should account for its provisional character. A revised version may be available directly from the author. 
IZA Discussion Paper No. 5869

July 2011

\section{ABSTRACT}

\section{Life Satisfaction and Grandparenthood: Evidence from a Nationwide Survey}

This paper tests whether there is a potential payoff to grandparenthood in terms of life satisfaction. Using the new nationwide survey for the UK, which consists of over 5,000 grandparents and 6,000 non-grandparents aged 40 and above, and a flexible multiple-index ordered probit model with varying thresholds, we find that being a grandparent to at least one grandchild is associated positively and statistically significantly with individuals reporting to be very satisfied with life overall. Parents with no grandchildren are no more satisfied with life compared to non-parents of the same age. The findings suggest that even though children may not contribute significantly to parents' satisfaction with life overall, there may well be long-term benefits to having children, provided that our children go on and have children of their own.

JEL Classification: J13

Keywords: life satisfaction, grandparenthood, grandchildren, generalized ordered probit, understanding society, happiness

Corresponding author:

Nattavudh Powdthavee

Division of Economics

School of Humanities \& Social Sciences

Nanyang Technological University

14 Nanyang Drive

Singapore, 637332

E-mail: n.powdthavee@ntu.edu.sg 


\section{Introduction}

There are perhaps no other studies in the psychological literature on well-being deemed as controversial by the general public as those which had found that children do not generally make us happy or becoming more satisfied with our life overall. Apart from a few notable exceptions (Kohler et al, 2005; Margolis \& Myrskylä, 2011), research in social science has found consistent evidence of either a zero or a negative correlation between the presence of children in a family and the respondent's self-rated well-being. For example, studies in the US and Europe have found that parents often reported slightly though statistically significantly lower levels of cognitive well-being such as marital satisfaction (White et al, 1986; Twenge et al, 2003) and life satisfaction (Powdthavee, 2008; Clark et al, 2008; Stanca, 2011), as well as affective well-being such as happiness (Alesina et al, 2004), mental health states (Cleary \& Mechanic, 1983; Shields \& Wheatley-Price, 2001; Clark \& Oswald, 2002) and moment-to-moment feelings (Kahneman et al, 2004; White \& Dolan, 2009) compared to nonparents. The finding's unpopularity has further been bolstered by the evidence that the strains associated with parenthood are not only limited to the period during which children are physically and economically dependent. For example, Glenn and McLanahan (1981) found those older parents whose children have left home report statistically the same level of happiness compared to nonparents of similar age and status.

One of the main reasons why many people have found the insignificant and sometimes negative correlation between the happiness and life satisfaction of parents and their fertility controversial is because it is deeply counterintuitive: Most of us would argue that although raising kids is hard work, we are nevertheless happy with our children, for our children and because of our children. Such beliefs are strong and prevalent across cultures, age groups, and genders (see, e.g., Blake, 1979; Baumeister, 1991). They are, however, 
frequently at odds with the scientific data. For example, when Americans were asked how their children have affected their marital lives, the majority concluded that the presence of children had affected their marriage in the most positive light possible. Yet when the same individuals were asked to report how satisfied they are with their marriage they ended up reporting lower levels of marital satisfaction than those who are either childless or childfree (Glenn \& McLanahan, 1982).

According to psychologist Daniel Gilbert (2006), the discrepancy between what we believe ("Children should make us happier!") and what the data actually tells us could be explained using evolutionary as well as psychological theories. For example, given that people who believe that there is no joy in parenthood - and who thus stop having children are less likely to pass on their beliefs any further beyond their generation, the belief that 'children bring happiness and satisfaction' will transmit itself much more successfully from generation to generation than the belief that 'children bring misery'. In other words, only the beliefs that have the best chance of transmission, even if they are faulty ones, will be passed on. In addition to this, when we believe that something makes us happy, we are willing to pay a high price for it. Yet it is also often the case that when we pay a high price for something, we rationalize that its possession makes us happier than when we did not possess it. And given that evolution passes on this unconditional and invariable compulsion to care for our children, it is therefore not surprising that we tend to rationalize those costs and conclude that our children must be repaying us with a deep sense of satisfaction.

More recently, the theory on focusing illusion (FT) has been put forward by a number of scholars as one of the key psychological explanations for why we tend to over-predict the impacts of many events in our lives, including the positive effects of children on how parents evaluate how their life has turned out (see, e.g., Schkade \& Kahneman, 1999; Powdthavee, 2009). When prompted to think about parenthood - either imagining future offspring or 
thinking about their current ones - the majority of people will tend to focus more of their attention on the good and salient things about being a parent (e.g., seeing our kids smile for the first time) and less so on the bad and seemingly trivial things about being a parent (e.g., the time spent changing dirty nappies and the frequent anxiety about the welfare of our children), partly because of the transmitted belief that children bring happiness. However, this does not negate the fact that the less salient experiences of parenthood - e.g., having more housework to do (Sanchez \& Thomson, 1997), time spent worrying about the household finance (Stanca, 2011), and less quality time with spouse (Crohan, 1996; Lavee et al, 1996) - do add up and are therefore likely to have daily emotional consequences. And given that too little weight will often be placed on the less salient experiences about being a parent, it should be no surprise why we tend to over-estimate the impacts children have, or could potentially have, on our overall life satisfaction whenever we are prompted to think about them.

What FI is implying is that the relationship between parenthood and life satisfaction is likely to be mediated by how the presence of children in the family affects parents' time-use and how their attentions are normally allocated on a daily basis. When individuals spend most of their time tending to the very core process of child care and being directly responsible for the child's well-being, then it may well be the case that they will always report significantly lower levels of life satisfaction compared to non-parents irrespective to what they might say when asked how much of their happiness can be credited to their children. This raises an important social science question: If our prediction about the impact of children on parents' life satisfaction is made incorrectly, could our prediction about the impact of grandchildren on grandparents' life satisfaction be any better? The null hypothesis, according to the FT theory, is that they should. Provided that most grandparents - especially in the western society - are often free from the direct financial and non-financial 
responsibilities to care for their grandchildren's welfare, e.g., they do not have to tend to the very core process of childcare with their grandchildren as they would have with their own children, it may well be that the net effect of children on grandparents' satisfaction with life overall is in fact positive and statistically significantly different from zero.

Due to data limitation, empirical evidence on the relationship between life satisfaction and grandparenthood is scarce and outdated. Two notable studies in this area are Kivnick (1982) and Thomas (1989). Based on qualitative data gathered from 30 grandparents and quantitative data gathered from 286 grandparents, Kivnick found activity level in the grandparent role to be generally unrelated to life satisfaction. By contrast, Thomas (1989) interviewed 301 grandparents about their relationship with their grandchildren and found that there is a positive relationship between the components of being a grandparent - e.g., indulging grandchildren and the feeling of immortality through their grandchild - and life satisfaction. Yet the above studies are based on very small samples of grandparents with no appropriate control groups (i.e., non-grandparents) and primarily qualitative in nature.

The current study aims to fill this research void by using the new large-scale British longitudinal data set to test whether there is any significant relationship between life satisfaction and grandparenthood. It estimates, perhaps the first of its kind, generalized ordered model of life satisfaction with a set of parenthood and grandparenthood statuses as explanatory variables. Thus, this paper attempts to contribute to the existing literature by exploring not only the possibility that grandchildren can impact our overall life satisfaction, but also whether the effect is greater at reducing dissatisfaction or at increasing the probability that the individual will report to be very satisfied with his or her life.

The research question of whether grandchildren contribute positively and significantly to the life satisfaction of grandparents is also important in its own right. Evidence of a 
positive relationship between grandparenthood and life satisfaction will imply that there is indeed a long-run psychological payoff to the investment of children, one that skips a generation.

\section{Data}

The data in this study comes from Wave 1 of the Understanding Society survey (http://www.understandingsociety.org.uk/). The Understanding Society survey is a major longitudinal study designed to provide new evidence about the people in the UK, their lives experiences, behaviours and beliefs. Starting from December 2009, the study follows 100,000 individuals from 40,000 households in Great Britain. The dependent variable used in the current study come from the responses to the life satisfaction (LS) question.

The LS question, which prompts survey respondents to rate themselves on a 7-pointscale based on how satisfied or dissatisfied they are with their life overall, is considered by psychologists as a standard gold measure of a person's cognitive well-being (Diener et al, 1985). It is formally defined as a global assessment of a person's quality of life according to a standard which each individual sets for him or herself (Shin \& Johnson, 1978). Responses to life satisfaction question are elicited using the following question: "All things considered, how satisfied or dissatisfied are you with your life overall using a 1-7 scale? 1 = very dissatisfied, ..., 7 = very satisfied”.

Our main explanatory variable is derived from (i) the "grandchildren living elsewhere" variable (a_lvrel5), the "children living elsewhere" variable (a_lvrel3), and (iii) the "relationship within household" variable (a_relationship). Here, the grandchildren variable takes a value of 1 if the respondent has at least one grandchild living in other 
households and/or there is at least one identifiable grandchild living in the same household as the respondent, and 0 otherwise. Similarly, the children variable takes a value of 1 if the respondent has at least one child living in other households and/or there is at least one identifiable child living in the same household as the respondent, and 0 otherwise. The two dummies are then interacted with each other to generate the "children and grandchildren" statuses, which consists of the following categories:

(a) Neither have children or grandchildren

(b) Have children but not grandchildren

(c) Have grandchildren but no alive children

(d) Have children and grandchildren

The (c) category is generated in order to allow for the confounding factor of losing one's child where there is at least one grandchild present. We restrict the sample to contain individuals aged 40 and above. This leaves us with a total sample of 11,942 observations. Of those, 5,246 are males, and 4,930 are over the age of 60 . Approximately $36 \%(\mathrm{~N}=4,275)$ reported not to have children and grandchildren who are still alive and living together with the respondent or residing in other households; $21 \%(\mathrm{~N}=2,538)$ reported to have children but no grandchildren; $1 \%(\mathrm{~N}=127)$ had grandchildren but no children who are alive; and approximately $42 \%(\mathrm{~N}=4,998)$ of the full sample reported to have both grandchildren and living children. It is possible to further differentiate the children and grandchildren status into those living with the respondent and those living in other households. However, given that the number of individuals who are living with at least one of their grandchildren is very small (around $6 \%$ of the total number of individuals who reported to have at least one grandchild, i.e. 317 from 5,125 ), differentiating them further into sub-groups is unlikely to influence our final estimates in a significant way and the decision is to keep the groupings as they are. Summary of descriptive statistics can be found in Table A1 in the Appendix. 


\section{Empirical strategy}

Most empirical work on the determinants of subjective well-being uses either linear regression or single-index ordered probit or logit estimators. The current study, however, follows the empirical strategy outlined in Boes and Winkelmann (2010) and Mentzakis (2011) and uses the generalised ordered probit (GOPROBIT) to estimate the effects of grandchildren on LS of grandparents for different parts of the LS distribution. The GOPROBIT estimator is preferred to other single-index ordered probit or logit models simply because it relaxes the assumption of implicit cardinalization such that the grandchildren effect must be constant across the distribution of life satisfaction responses (Boes \& Winkelmann, 2006), and therefore enables unrestricted grandchildren effects for low and high levels of LS to be estimated. In other words, the current study allows for the possibility that grandchildren may help reduce dissatisfaction - i.e., the probability that the respondent will place himself on the lower rungs of the life satisfaction scale - more than they help increase satisfaction for the respondents.

To formulate the GOPROBIT model, let $L S_{i} \in\{1, \ldots, J\}$ denote self-reported LS of individual $i=1, \ldots, n$, and $x_{i}$ to represent a vector of covariates which includes the respondent's grandchildren (or grandparenthood) dummies. The relationship between $L S_{i}$ and $x_{i}$ can then be written in terms of cumulative conditional probabilities as followed:

$$
P\left(L S_{i} \leq j \mid x_{i} ; \theta_{j}\right)=\Phi\left(-x_{i} \theta_{j}\right) \quad j=1, \ldots, J-1
$$

where $\Phi($.$) denotes the cumulative density function of the standard normal distribution, and$ $\theta_{j}$ represents a vector of category-specific parameters including a constant term. In order to 
ensure positive cell probabilities, it is required that $\theta_{j}$ fulfill the strict inequalities $x_{i} \theta_{1}>\ldots>x_{i} \theta_{J-1}$. Rewrite $x_{i} \theta_{j}$ as

$$
x_{i} \theta_{j}=\alpha_{i}+\tilde{x}_{i} \beta_{j} \quad j=1, \ldots, J-1
$$

Equation (2) becomes the standard ordered probit when all the slope parameters are restricted to be equal across the well-being distribution, i.e. $\beta_{1}=\ldots=\beta_{J-1}$. However, in the generalized ordered probit such a restriction is not imposed. Rather, a set of coefficients on the covariates, $x_{i}$, is estimated for each of the $J-1$ points of the LS scale (for a detailed description of the GOPROBIT model, see Boes \& Winkelmann, 2006). All regressions are estimated using STATA version 11.1 with robust standard errors.

\section{Results}

Are grandparents more satisfied with their life compared to non-grandparents? To provide a first pass to this question, we present in Figure 1 a summary of mean LS scores by grandchildren statuses for those who are aged 40 and above. A naïve comparison of these averages tells us that (i) there is no statistical difference in the average LS scores between non-parents and parents who are non-grandparents, (ii) respondents who have grandchildren but no living children are significantly dissatisfied with their life, and (iii) grandparents with living children are clearly the most satisfied people out of the four groups. The grandparents with living children have an average LS score of $5.45(S . E .=0.021)$, while the average LS scores for nonparents, parents with no grandchildren, and parents with grandchildren but no living children are $5.27($ S.E. $=0.013), 5.23($ S.E. $=0.027)$, and $4.82($ S.E. $=0.142)$, respectively. The relationships are, however, likely to be confounded by the age effects, i.e., 
older cohorts are likely to become grandparents and are also likely to be more satisfied with their lives compared to younger cohorts (Blanchflower \& Oswald, 2008).

The standard ordered probit (OPROBIT) estimates and the generalized ordered probit (GPROBIT) estimates on the relationship between LS and grandparenthood are reported in Table 1 . In the generalized model, six different parameters vectors $\theta_{1}, \ldots, \theta_{6}$ are estimated (where each vector contains coefficients for all the explanatory variables). With no additional controls (Panel A), the estimated OPROBIT coefficients on "Have children but no grandchildren" and "Have both children and grandchildren" are positive and statistically significant at the $1 \%$ level, while the coefficient on "Have grandchildren but no living children" is negative and statistically well-determined at the 5\% level. By contrast, the GOPROBIT coefficients vary in terms of signs and statistical significance across the parameters. For example, the estimated coefficients on "Have both children and grandchildren" are positive and statistically well-determined at conventional levels for mid to high LS, i.e., $\theta_{3}, \theta_{4}, \theta_{5}$ and $\theta_{6}$, and negative and statistically significant for low LS, i.e., $\theta_{1}$ and $\theta_{2}$.

Panel B of Table 1 controls for exogenous variables, adding age, age-squared, race and gender of the respondent. Apart from the estimated coefficient on "Have grandchildren but no living children" which continues to be negative and statistically significant at the $1 \%$ level, the OPROBIT coefficients on both i) parents but no grandchildren and ii) parents and grandparents have now lost their statistical significances once age, age-squared, gender, and race are held constant in the estimation. By relaxing the parallel regression assumption, however, the coefficients obtained from the GOPROBIT model suggest that having children, regardless of whether or not the respondent also has at least one grandchild, continues to be negative and statistically significant at the $5 \%$ level for $\theta_{1}$ and $\theta_{2}$. Yet the point estimates for 
"Have children but no grandchildren" for $\theta_{4}, \theta_{5}$ and $\theta_{6}$ turn statistically insignificant when exogenous variables are controlled for in the estimation. However, the estimated coefficient on "Have both children and grandchildren" continues to be positive and statistically significant at the $1 \%$ level for $\theta_{6}(0.118$ with a robust standard error of 0.041$)$, while the estimated coefficients for those who have grandchildren but no living children continue to be negative and statistically well-determined at conventional levels for $\theta_{1}$ through to $\theta_{5}$.

Panel $\mathrm{C}$ of Table 1 turns to OPROBIT and GOPROBIT regressions with full specification, adding dummy variables for marital statuses, employment statuses, subjective health statuses, and regions, as well as log of household income and age left full-time education. Whilst many of the coefficients have lost significance, it is interesting to see that, even with full controls, the point estimate for "Having both children and grandchildren" in the GOPROBIT model hardly changes; it remains positive and statistically significant at the $5 \%$ level for $\theta_{6}(0.112$ with a robust standard error of 0.044$)$. See Table A2 in the appendix for the estimates of the control variables.

With regards to the model selection, a Wald test on the GOPROBIT model with fullspecification suggests that we can reject the null hypothesis of equal slope parameters ( $\left.\chi_{219}^{2}=14,722.95\right)$, thereby rejecting the implicit assumption of cardinalization under the standard model in favour for the generalized model. The result thus suggests that parameters are heterogeneous with respect to the LS responses.

Since the OPROBIT and GOPROBIT coefficients are not straightforward to interpret, we present in Table 2 the estimated marginal probability effects (MPE), or $\frac{\partial P(y=j \mid x)}{\partial x}$, obtained from the regressions in Panel C of Table 1 (Boes \& Winkelmann, 2006). Comparing the MPEs among the standard and the generalized models over all outcomes produces the 
following conclusions. First, whilst the standard model predicts statistically insignificant effects of "Have children but no grand children" and "Have both children and grandchildren" for each category of LS, the generalized model predicts that being a grandparent to at least one person is associated, on average, with an increase in the probability of individual reporting "7" or "very satisfied" on the LS scale by approximately 2.4-percentage-points. Second, having only grandchildren but no living children is predicted in the standard model to increase the probability of responses "5" and lower, whilst reduces the probability of responses " 6 " and higher. The equivalent effects are, however, statistically significant only for high LS responses (6-7) in the generalized model.

Following the work by Margolis and Myrskylä (2011) and Stanca (2011), who explored the interaction effects between children and the parent's socio-economic status on LS, Table 4 turns to the estimated MPEs of grandchildren on LS by gender (Panels A-B), education (Panels C-D), income group (Panels E-F), and age group of the respondents (Panel G-H). Looking across panels, the effects of "Have both children and grandchildren" on high LS, i.e. LS = "7", are positive and statistically well-determined only for women, people who completed more than 15 years of full-time education, individuals with income above the sample average, and those aged between 40 and 59. For instance, having both children and grandchildren increases the probability of reporting "7" on the LS scale by 3.1-percentagepoints for women, 2.4-percentage-points for the (relatively) highly educated, 4.1-percentagepoints for the (relatively) rich, and 4.2-percentage-points for the younger cohorts. These results are consistent with what had been found in previous studies with respect to the impacts of own children on LS (Margolis \& Myrskylä, 2011; Stanca, 2011). Nevertheless, apart from the " $40<$ age $\leq 60$ " age group, we find the effects of own children without grandchildren on LS to be mostly insignificant here in our sub-sample regressions. In addition to this, it is interesting to see how the estimated grandchildren effect on high LS is 
more positive when the respondents (and implicitly, his or her grandchildren) are still relatively young.

In summary, these results suggest that there is a positive and statistically important relationship between life satisfaction and grandparenthood, conditioning on own children being alive. However, there seems to be considerable heterogeneity on the grandchildren effects with respect to the LS distribution, i.e., the estimated impacts are significant only for high LS.

\section{Concluding remarks}

This paper investigates the relatively unexplored relationship between grandparenthood and self-rated life satisfaction. Using the new Understanding Society survey for the UK, which surveyed more than 5,000 grandparents and over 6,000 of non-grandparents (aged 40 years and above) nation-wide, we find that there is indeed a positive and statistically important correlation between having grandchildren and how the respondent rated his or her satisfaction with life overall. However, it appears that the positive relationship is only confined to the very top of the life satisfaction distribution. What this implies is that the presence of at least one grandchild - conditioning on parents being alive - does not significantly reduce one's dissatisfaction. Rather, it increases the probability of the individual reporting to be "very satisfied" with his or her life overall. Such a heterogeneous effect of grandchildren on life satisfaction is deemed consistent with the recently established notion that the determinants of positive and negative well-being are not necessarily the same (see, e.g., Huppert \& Whittington, 2003; Boes \& Winkelmann, 2010). By contrast, the relationship between children and life satisfaction, conditioning on having no grandchildren, is generally 
statistically insignificant at least at the $5 \%$ level in all but one sub-group regression, i.e., the “40 $\leq$ age $<60 "$ group.

Overall, our results indicate that being a grandparent to at least one grandchild is associated positively with becoming more satisfied with life even when parenthood itself may not. The suspected impact is, however, marginal rather than applied averagely across the distribution of life satisfaction. Implicitly, our findings imply that an investment in children may have a long-term psychological payoff, providing that our children also go on to have children of their own.

This paper is, however, not without limitations. The first is that it is hard to establish causality between life satisfaction and grandparenthood. The exogeneity of grandchildren is, by and large, debatable. While the choice of whether or not our children will go on to have their own children is arguably weakly linked to our life satisfaction, it remains possible that there are some omitted third variables that correlate with our desire (and our children's desire) to pass on our genes and the way we evaluate how satisfied we are with our lives overall. In addition to this, due to data limitation, we are unable to control for the number of grandchildren in our regression equations. It may well be the case that quantity matters as much as quality. Future research should return to examine whether the positive correlation between grandparenthood and life satisfaction at the higher end of the life satisfaction score varies according to the number of grandchildren the respondent has. 


\section{Reference}

Alesina, Alberto; Di Tella, Rafael; and MacCulloch, Robert. 2004. Inequality and happiness: are Europeans and American different? Journal of Public Economics, 88, 2009-2042.

Baumeister, Roy F. 1991. Meanings of life. New York: Guilford Press.

Blake, Judith. 1979. Is zero preferred? American attitudes toward childlessness in the 1970s. Journal of Marriage and the Family, 41, 245-257.

Blanchflower, David G., Oswald, Andrew J. 2008. Is well-being U-shaped over the life cycle? Social Science \& Medicine, 66, 1733-1749.

Boes, S., Winkelmann, R. 2006. Ordered response models. Allgemeines Statistisches Archiv, $90,165-179$.

Boes, Stefan, Winkelmann, Rainer. 2010. The effect of income on general life satisfaction and dissatisfaction. Social Indicators Research, 95, 111-128.

Clark, Andrew E.; Diener, Ed; Georgellis, Yannis; Lucas, Richard E. 2008. Lags and leads in life satisfaction: a test of the baseline hypothesis. Economic Journal, 118, F222-243.

Clark, Andrew E., Oswald, Andrew J. 2002. Well-being in panels. Unpublished manuscript, Department of Economics, University of Warwick.

Cleary, Paul D., Mechanic, David. 1983. Sex differences in psychological distress among married people. Journal of Health and Social Behaviour, 24, 111-121.

Crohan, Susan E. 1996. Marital quality and conflict across the transition to parenthood in African American and white couples. Journal of Marriage and the Family, 58, 933-944.

Diener, Ed; Emmons, Robert A.; Larsen, Randy J.; and Griffin, Sharon. 1985. The satisfaction with life scale. Journal of Personality Assessment, 49, 71-75.

Gilbert, Daniel T. 2006. Stumbling on Happiness. HarperCollins. 
Glenn, Norval D.; McLanahan, Sara. 1981. The effect of children on the psychological wellbeing of older adults. Journal of Marriage and Family, 43, 409-421.

Glenn, Norval D.; McLanahan, Sara. 1982. Children and marital happiness: a further specification of the relationship. Journal of Marriage and Family, 44, 63-72.

Huppert, Felicia A., Whittington, Joyce E. 2003. Evidence for the independence of positive and negative well-being: Implications for quality of life assessment. British Journal of Health Psychology, 8, 107-122.

Kivnick, Helen Q. 1982. Grandparenthood: an overview of meaning and mental health. Gerontologist, 22, 59-66.

Kohler, Hans-Peter; Behrman, Jere R.; and Skytthe, Axel. 2005. Partner plus children = happiness? The effects of partnerships and fertility on well-being. Population and Development Review 31, 407-445.

Lavee, Yoav; Sharlin, Shlomo; and Katz, Ruth. 1996. The effect of parenting stress on marital quality: an integrated mother-father model. Journal of Family Issues, 17, 114-135.

Margolis, R., Myrskylä, M. 2011. A global perspective on happiness and fertility. Population and Development Review, forthcoming.

Mentzakis, Emmanouli. 2011. Allowing for heterogeneity in monetary subjective well-being valuations. Health Economics, 20, 331-347.

Powdthavee, Nattavudh. 2008. Putting a price tag on friends, relatives, and neighbours: using surveys of life satisfaction to value social relationships. Journal of Socio-Economics, 37(4), $1459-1480$.

Powdthavee, Nattavudh. 2009. Think having children will make you happy? The Psychologist, 22, 308-311.

Sanchez, Laura; Thomson, Elizabeth. 1997. Becoming mothers and fathers: parenthood, gender, and the division of labour. Gender \& Society, 11, 747-772. 
Shields, Michael A., Wheatley-Price, Stephen. 2001. Exploring the economic and social determinants of psychological and psychosocial health. IZA Discussion Paper \#396.

Shin, D.C., Johnson, D.M. 1978. Avowed happiness as an overall assessment of the quality of life. Social Indicators Research, 5, 475-492.

Stanca, Luca. 2011. Suffer the little children: measuring the effects of parenthood on wellbeing worldwide. Journal of Economic Behavior \& Organization, forthcoming.

Thomas, Jeane L. 1989. Gender and perceptions of grandparenthood. The International Journal of Aging and Human Development, 29, 269-282.

Twenge, Jean M.; Campbell, W.Keith; and Foster, Craig A. 2003. Parenthood and marital satisfaction: a meta-analytic review. Journal of Marriage and Family, 65(3), 574-583.

White, Lynn K.; Booth, Alan; and Edwards, John N. 1986. Children and marital happiness: why the negative correlation? Journal of Family Issues, 7, 131-147.

White, Mathew P.; Dolan, Paul. 2009. Account for the richness of daily activities. Psychological Science, 20, 1000-1008. 


\section{Figure 1: Life Satisfaction, Children, and Grandchildren}

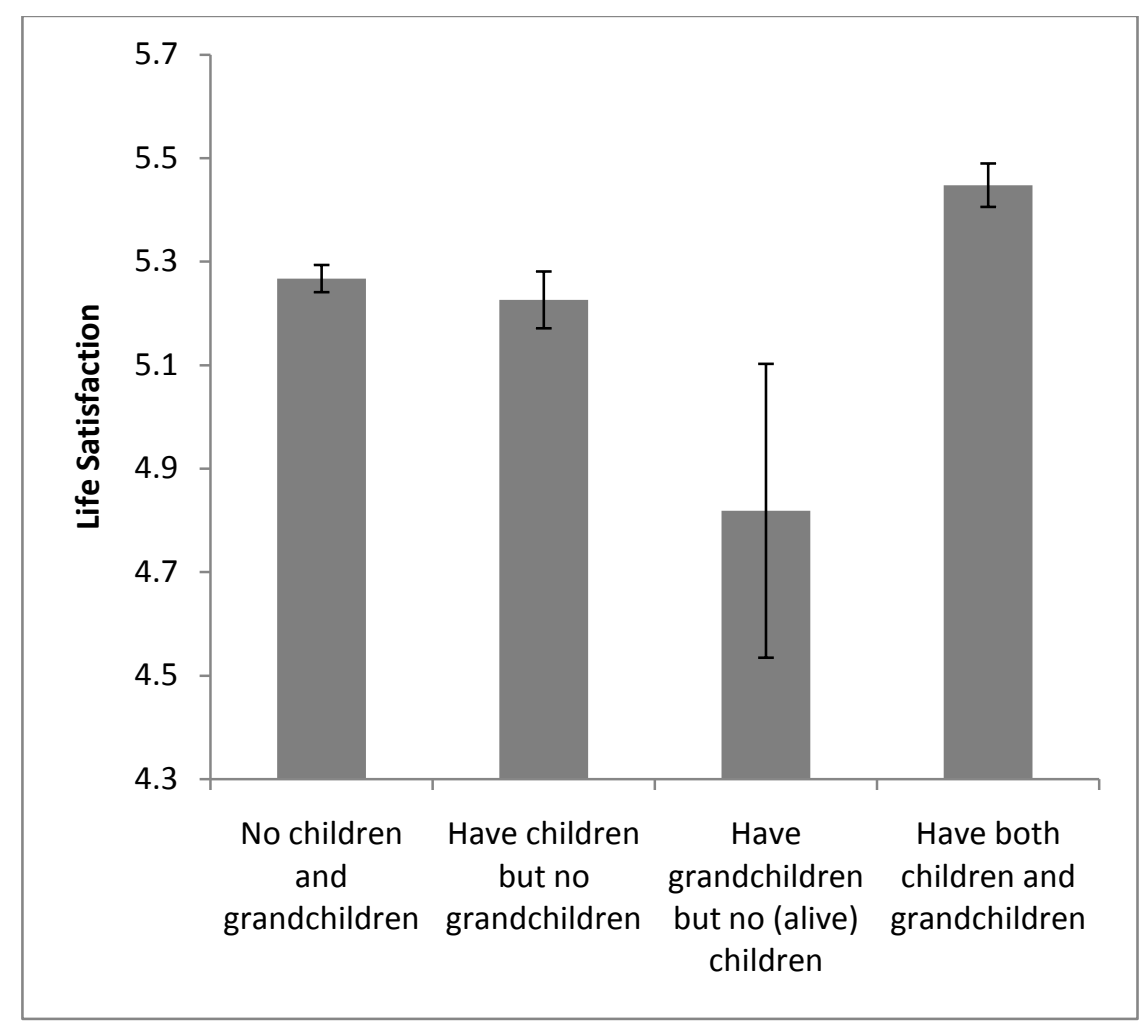

Note: 4-standard-error bands (95\% C.I.) are reported: two s.e. above and two below. 
Table 1: Standard and Generalized Ordered Probit Life Satisfaction Models with Grandchildren as Explanatory Variables

\begin{tabular}{|c|c|c|c|c|c|c|c|}
\hline $\begin{array}{l}\text { Panel A: } \\
\text { No control } \\
\text { variables }\end{array}$ & $\begin{array}{l}\text { OPROBIT } \\
\text { Overall }\end{array}$ & $\begin{array}{c}\text { GOPROBIT } \\
\theta_{1} \\
\end{array}$ & $\boldsymbol{\theta}_{2}$ & $\theta_{3}$ & $\boldsymbol{\theta}_{4}$ & $\theta_{5}$ & $\theta_{6}$ \\
\hline \multirow{2}{*}{$\begin{array}{l}\text { Have children but no } \\
\text { grandchildren }\end{array}$} & $0.0850 * *$ & $-0.133 *$ & -0.0594 & 0.0344 & $0.0884 *$ & $0.105^{* *}$ & $0.156^{* *}$ \\
\hline & {$[0.0256]$} & {$[0.0676]$} & {$[0.0471]$} & {$[0.0388]$} & {$[0.0346]$} & {$[0.0318]$} & [0.0400] \\
\hline \multirow{2}{*}{$\begin{array}{l}\text { Have grandchildren but } \\
\text { no living children }\end{array}$} & $-0.194 *$ & $-0.360+$ & $-0.415^{* *}$ & $-0.218+$ & $-0.276^{*}$ & $-0.255^{*}$ & 0.0378 \\
\hline & [0.0974] & [0.195] & [0.141] & {$[0.128]$} & [0.116] & [0.113] & [0.148] \\
\hline \multirow{2}{*}{$\begin{array}{l}\text { Have both children and } \\
\text { grandchildren }\end{array}$} & $0.245^{* *}$ & $-0.167 * *$ & -0.0157 & $0.121 * *$ & $0.182 * *$ & $0.246^{* *}$ & $0.399 * *$ \\
\hline & [0.0219] & {$[0.0568]$} & {$[0.0400]$} & {$[0.0330]$} & [0.0292] & {$[0.0266]$} & [0.0324] \\
\hline \multirow{2}{*}{$\begin{array}{l}\text { Panel B: } \\
\text { Exogenous variables as } \\
\text { controls }\end{array}$} & & & & & & & \\
\hline & $\begin{array}{l}\text { OPROBIT } \\
\text { Overall }\end{array}$ & $\begin{array}{c}\text { GOPROBIT } \\
\theta_{1} \\
\end{array}$ & $\boldsymbol{\theta}_{2}$ & $\boldsymbol{\theta}_{3}$ & $\boldsymbol{\theta}_{4}$ & $\theta_{5}$ & $\theta_{6}$ \\
\hline \multirow{2}{*}{$\begin{array}{l}\text { Have children but no } \\
\text { grandchildren }\end{array}$} & -0.00742 & $-0.163 *$ & $-0.102^{*}$ & -0.0396 & 0.000924 & -0.00186 & 0.0395 \\
\hline & [0.0269] & [0.0709] & [0.0495] & [0.0404] & {$[0.0362]$} & {$[0.0334]$} & [0.0423] \\
\hline \multirow{2}{*}{$\begin{array}{l}\text { Have grandchildren but } \\
\text { no living children }\end{array}$} & $-0.390 * *$ & $-0.397 *$ & $-0.486 * *$ & $-0.366 * *$ & $-0.451 * *$ & $-0.465 * *$ & -0.228 \\
\hline & [0.0962] & [0.198] & {$[0.146]$} & [0.131] & {$[0.118]$} & {$[0.112]$} & {$[0.150]$} \\
\hline \multirow{2}{*}{$\begin{array}{l}\text { Have both children and } \\
\text { grandchildren }\end{array}$} & 0.00418 & $-0.235 * *$ & $-0.138 * *$ & $-0.0756+$ & -0.0445 & -0.0154 & $0.118 * *$ \\
\hline & [0.0279] & {$[0.0685]$} & [0.0493] & {$[0.0405]$} & [0.0367] & {$[0.0338]$} & [0.0409] \\
\hline $\begin{array}{l}\text { Panel C: } \\
\text { Full } \\
\text { controls }\end{array}$ & $\begin{array}{l}\text { OPROBIT } \\
\text { Overall }\end{array}$ & $\begin{array}{c}\text { GOPROBIT } \\
\theta_{1}\end{array}$ & $\boldsymbol{\theta}_{2}$ & $\boldsymbol{\theta}_{3}$ & $\theta_{4}$ & $\theta_{5}$ & $\theta_{6}$ \\
\hline \multirow{2}{*}{$\begin{array}{l}\text { Have children but no } \\
\text { grandchildren }\end{array}$} & 0.00913 & $-0.154+$ & $-0.122 *$ & -0.0191 & 0.0223 & 0.0175 & 0.0463 \\
\hline & [0.0279] & {$[0.0806]$} & {$[0.0530]$} & [0.0430] & [0.0387] & {$[0.0354]$} & [0.0446] \\
\hline \multirow{2}{*}{$\begin{array}{l}\text { Have grandchildren but } \\
\text { no living children }\end{array}$} & $-0.354 * *$ & -0.357 & $-0.415^{* *}$ & $-0.270^{*}$ & $-0.390 * *$ & $-0.373 * *$ & $-0.290+$ \\
\hline & [0.102] & {$[0.220]$} & {$[0.161]$} & [0.129] & {$[0.128]$} & {$[0.123]$} & {$[0.157]$} \\
\hline \multirow{2}{*}{$\begin{array}{l}\text { Have both children and } \\
\text { grandchildren }\end{array}$} & 0.0469 & $-0.152 *$ & -0.0701 & -0.0225 & 0.0261 & 0.0565 & $0.112^{*}$ \\
\hline & [0.0293] & {$[0.0770]$} & {$[0.0550]$} & {$[0.0443]$} & {$[0.0398]$} & {$[0.0362]$} & {$[0.0437]$} \\
\hline
\end{tabular}

Note: $\mathrm{N}=11,849$. Life satisfaction is measured on a 7-point-scale, with $1=$ very dissatisfied, ..., and 7=very satisfied. Control variables in the full specification include age, age-squared, gender, race dummies, subjective health statuses, age left full-time education, log of household income, employment dummies, marital statuses, and regional dummies. Robust standard errors are in parentheses. $+<10 \% ; *<5 \%$; $* *<1 \%$. 
Table 2: Marginal Probability Effects by Satisfaction Level

\begin{tabular}{|c|c|c|c|c|c|c|c|}
\hline \multirow[t]{2}{*}{ Marginal probability effects } & \multicolumn{7}{|c|}{ Satisfaction level } \\
\hline & 1 & 2 & 3 & 4 & 5 & 6 & 7 \\
\hline \multicolumn{8}{|l|}{ A. Ordered Probit } \\
\hline Have children but no grandchildren & $\begin{array}{l}-0.0003 \\
{[0.001]}\end{array}$ & $\begin{array}{l}-0.001 \\
{[0.001]}\end{array}$ & $\begin{array}{c}-0.001 \\
{[0.002]}\end{array}$ & $\begin{array}{l}-0.001 \\
{[0.002]}\end{array}$ & $\begin{array}{c}-0.001 \\
{[0.002]}\end{array}$ & $\begin{array}{c}0.001 \\
{[0.004]}\end{array}$ & $\begin{array}{c}0.002 \\
{[0.006]}\end{array}$ \\
\hline Have grandchildren but no living children & $\begin{array}{c}0.02 \\
{[0.008]^{*}}\end{array}$ & $\begin{array}{c}0.028 \\
{[0.009]^{* *}}\end{array}$ & $\begin{array}{c}0.032 \\
{[0.010] * *}\end{array}$ & $\begin{array}{c}0.031 \\
{[0.008]^{* *}}\end{array}$ & $\begin{array}{c}0.026 \\
{[0.004] * *}\end{array}$ & $\begin{array}{c}-0.076 \\
{[0.026] * *}\end{array}$ & $\begin{array}{c}-0.062 \\
{[0.014]^{* *}}\end{array}$ \\
\hline Have both children and grandchildren & $\begin{array}{l}-0.001 \\
{[0.001]}\end{array}$ & $\begin{array}{c}-0.003 \\
{[0.001]}\end{array}$ & $\begin{array}{c}-0.004 \\
{[0.002]}\end{array}$ & $\begin{array}{c}-0.004 \\
{[0.002]}\end{array}$ & $\begin{array}{c}-0.004 \\
{[0.003]}\end{array}$ & $\begin{array}{c}0.007 \\
{[0.004]}\end{array}$ & $\begin{array}{c}0.010 \\
{[0.006]}\end{array}$ \\
\hline \multicolumn{8}{|l|}{ B. Generalized Ordered Probit } \\
\hline Have children but no grandchildren & $\begin{array}{c}0.007 \\
{[0.004]+}\end{array}$ & $\begin{array}{c}0.008 \\
{[0.006]}\end{array}$ & $\begin{array}{c}-0.011 \\
{[0.006]+}\end{array}$ & $\begin{array}{l}-0.009 \\
{[0.007]}\end{array}$ & $\begin{array}{c}0.000 \\
{[0.010]}\end{array}$ & $\begin{array}{l}-0.003 \\
{[0.014]}\end{array}$ & $\begin{array}{c}0.010 \\
{[0.010]}\end{array}$ \\
\hline Have grandchildren but no living children & 0.020 & 0.043 & -0.003 & 0.063 & 0.021 & -0.092 & -0.053 \\
\hline Have both children and grandchildren & $\begin{array}{c}{[0.018]} \\
0.006 \\
{[0.003]+}\end{array}$ & $\begin{array}{c}{[0.026]+} \\
0.002 \\
{[0.005]} \\
\end{array}$ & $\begin{array}{c}{[0.022]} \\
-0.004 \\
{[0.006]} \\
\end{array}$ & $\begin{array}{c}{[0.034]+} \\
-0.011 \\
{[0.007]} \\
\end{array}$ & $\begin{array}{c}{[0.039]} \\
-0.014 \\
{[0.010]} \\
\end{array}$ & $\begin{array}{c}{[0.046]^{*}} \\
-0.003 \\
{[0.014]} \\
\end{array}$ & $\begin{array}{c}{[0.024]^{*}} \\
0.024 \\
{[0.009]^{*}}\end{array}$ \\
\hline
\end{tabular}

Note: The marginal probability effects are based on the estimated coefficients obtained from Panel C, Table 1 . Robust standard errors are in parentheses. $+<10 \%$; $*<5 \%$; $* *<1 \%$. 
Table 3: Marginal Probability Effects by Satisfaction Level and by Group

\begin{tabular}{|c|c|c|c|c|c|c|c|}
\hline \multirow{2}{*}{$\begin{array}{l}\text { Marginal probability effects } \\
\text { GOPROBIT models }\end{array}$} & \multicolumn{7}{|c|}{ Satisfaction level } \\
\hline & 1 & 2 & 3 & 4 & 5 & 6 & 7 \\
\hline \multicolumn{8}{|l|}{ A. $\operatorname{Men}(N=5,197)$} \\
\hline Have children but no grandchildren & $\begin{array}{c}0.00773 \\
{[0.00621]}\end{array}$ & $\begin{array}{c}0.00529 \\
{[0.00888]}\end{array}$ & $\begin{array}{c}-0.0161 \\
{[0.00994]}\end{array}$ & $\begin{array}{c}-0.0156 \\
{[0.0113]}\end{array}$ & $\begin{array}{c}-0.0073 \\
{[0.0157]}\end{array}$ & $\begin{array}{c}0.0229 \\
{[0.0201]}\end{array}$ & $\begin{array}{l}0.00307 \\
{[0.0132]}\end{array}$ \\
\hline Have grandchildren but no living children & $\begin{array}{l}0.305^{*} \\
{[0.131]}\end{array}$ & $\begin{array}{l}0.370 * * \\
{[0.136]}\end{array}$ & $\begin{array}{c}-0.725^{* *} \\
{[0.169]}\end{array}$ & $\begin{array}{c}0.0493 \\
{[0.0558]}\end{array}$ & $\begin{array}{c}0.0738 \\
{[0.0675]}\end{array}$ & $\begin{array}{c}-0.0532 \\
{[0.0762]}\end{array}$ & $\begin{array}{r}-0.0200 \\
{[0.0410]}\end{array}$ \\
\hline Have both children and grandchildren & $\begin{array}{c}0.00458 \\
{[0.00521]}\end{array}$ & $\begin{array}{c}-0.00026 \\
{[0.00882]}\end{array}$ & $\begin{array}{c}0.00374 \\
{[0.0107]}\end{array}$ & $\begin{array}{c}-0.0287 * \\
{[0.0122]}\end{array}$ & $\begin{array}{c}-0.0269 \\
{[0.0169]}\end{array}$ & $\begin{array}{c}0.0268 \\
{[0.0210]}\end{array}$ & $\begin{array}{c}0.0206 \\
{[0.0133]}\end{array}$ \\
\hline \multicolumn{8}{|l|}{ B. Women $(\mathrm{N}=6,652)$} \\
\hline Have children but no grandchildren & $\begin{array}{c}0.00457 \\
{[0.00304]}\end{array}$ & $\begin{array}{c}0.0120 \\
{[0.00894]}\end{array}$ & $\begin{array}{c}-0.00688 \\
{[0.00920]}\end{array}$ & $\begin{array}{c}-0.00333 \\
{[0.00980]}\end{array}$ & $\begin{array}{l}0.00606 \\
{[0.0148]}\end{array}$ & $\begin{array}{c}-0.0263 \\
{[0.0196]}\end{array}$ & $\begin{array}{c}0.0138 \\
{[0.0143]}\end{array}$ \\
\hline Have grandchildren but no living children & $\begin{array}{c}-0.0076 * * \\
{[0.000931]}\end{array}$ & $\begin{array}{c}-0.0137 \\
{[0.0218]}\end{array}$ & $\begin{array}{c}0.0388 \\
{[0.0325]}\end{array}$ & $\begin{array}{c}0.0949+ \\
{[0.0498]}\end{array}$ & $\begin{array}{l}0.00653 \\
{[0.0542]}\end{array}$ & $\begin{array}{c}-0.0567 \\
{[0.0643]}\end{array}$ & $\begin{array}{l}-0.0622+ \\
{[0.0333]}\end{array}$ \\
\hline Have both children and grandchildren & $\begin{array}{c}0.00305 \\
{[0.00203]}\end{array}$ & $\begin{array}{c}0.00492 \\
{[0.00758]}\end{array}$ & $\begin{array}{c}-0.00593 \\
{[0.00809]}\end{array}$ & $\begin{array}{l}0.000375 \\
{[0.00920]}\end{array}$ & $\begin{array}{c}-0.0063 \\
{[0.0142]}\end{array}$ & $\begin{array}{c}-0.0266 \\
{[0.0189]}\end{array}$ & $\begin{array}{l}0.0305^{*} \\
{[0.0136]}\end{array}$ \\
\hline \multicolumn{8}{|l|}{ C. Age left school $<=15$ years $(N=4,485)$} \\
\hline Have children but no grandchildren & $\begin{array}{c}0.0141 \\
{[0.0113]}\end{array}$ & $\begin{array}{l}-0.00130 \\
{[0.0123]}\end{array}$ & $\begin{array}{l}-0.00669 \\
{[0.0118]}\end{array}$ & $\begin{array}{c}-0.0226 \\
{[0.0152]}\end{array}$ & $\begin{array}{c}-0.0148 \\
{[0.0204]}\end{array}$ & $\begin{array}{c}0.0167 \\
{[0.0282]}\end{array}$ & $\begin{array}{c}0.0146 \\
{[0.0235]}\end{array}$ \\
\hline Have grandchildren but no living children & $\begin{array}{c}0.0320 \\
{[0.0369]}\end{array}$ & $\begin{array}{c}0.0147 \\
{[0.0380]}\end{array}$ & $\begin{array}{c}0.0128 \\
{[0.0347]}\end{array}$ & $\begin{array}{l}-0.00825 \\
{[0.0409]}\end{array}$ & $\begin{array}{c}-0.0154 \\
{[0.0530]}\end{array}$ & $\begin{array}{c}0.0296 \\
{[0.0663]}\end{array}$ & $\begin{array}{r}-0.0654 \\
{[0.0458]}\end{array}$ \\
\hline Have both children and grandchildren & $\begin{array}{c}0.0128+ \\
{[0.00673]}\end{array}$ & $\begin{array}{c}-0.00770 \\
{[0.00920]}\end{array}$ & $\begin{array}{c}0.00774 \\
{[0.00971]}\end{array}$ & $\begin{array}{c}-0.0223 \\
{[0.0138]}\end{array}$ & $\begin{array}{c}-0.0219 \\
{[0.0187]}\end{array}$ & $\begin{array}{l}0.00564 \\
{[0.0244]}\end{array}$ & $\begin{array}{c}0.0257 \\
{[0.0192]}\end{array}$ \\
\hline \multicolumn{8}{|l|}{ D. Age left school > 15 years $(\mathrm{N}=7,364)$} \\
\hline Have children but no grandchildren & $\begin{array}{c}0.00322 \\
{[0.00362]}\end{array}$ & $\begin{array}{c}0.0115+ \\
{[0.00656]}\end{array}$ & $\begin{array}{c}-0.0163 * \\
{[0.00779]}\end{array}$ & $\begin{array}{c}-0.00543 \\
{[0.00881]}\end{array}$ & $\begin{array}{l}0.00480 \\
{[0.0126]}\end{array}$ & $\begin{array}{c}-0.0108 \\
{[0.0162]}\end{array}$ & $\begin{array}{c}0.0130 \\
{[0.0103]}\end{array}$ \\
\hline Have grandchildren but no living children & $\begin{array}{c}0.0365 \\
{[0.0365]}\end{array}$ & $\begin{array}{c}0.0699 \\
{[0.0467]}\end{array}$ & $\begin{array}{c}-0.0384 \\
{[0.0409]}\end{array}$ & $\begin{array}{c}0.123^{*} \\
{[0.0583]}\end{array}$ & $\begin{array}{c}0.0404 \\
{[0.0598]}\end{array}$ & $\begin{array}{c}-0.190 * * \\
{[0.0650]}\end{array}$ & $\begin{array}{l}-0.0414 \\
{[0.0315]}\end{array}$ \\
\hline
\end{tabular}




\begin{tabular}{|c|c|c|c|c|c|c|c|}
\hline Have both children and grandchildren & $\begin{array}{c}0.00250 \\
{[0.00353]}\end{array}$ & $\begin{array}{c}0.00695 \\
{[0.00681]}\end{array}$ & $\begin{array}{c}-0.0135 \\
{[0.00844]}\end{array}$ & $\begin{array}{c}-0.0122 \\
{[0.00991]}\end{array}$ & $\begin{array}{c}-0.0084 \\
{[0.0138]}\end{array}$ & $\begin{array}{l}0.00113 \\
{[0.0181]}\end{array}$ & $\begin{array}{c}0.0236^{*} \\
{[0.0114]}\end{array}$ \\
\hline \multicolumn{8}{|l|}{ E. Income $<=$ Mean income $(N=5,849)$} \\
\hline Have children but no grandchildren & $\begin{array}{c}0.0159 * \\
{[0.00802]}\end{array}$ & $\begin{array}{c}0.0163 \\
{[0.0111]}\end{array}$ & $\begin{array}{l}-0.00127 \\
{[0.0123]}\end{array}$ & $\begin{array}{l}0.00618 \\
{[0.0132]}\end{array}$ & $\begin{array}{c}-0.0081 \\
{[0.0182]}\end{array}$ & $\begin{array}{c}-0.0237 \\
{[0.0224]}\end{array}$ & $\begin{array}{c}-0.00534 \\
{[0.0165]}\end{array}$ \\
\hline Have grandchildren but no living children & $\begin{array}{c}0.0106 \\
{[0.0241]}\end{array}$ & $\begin{array}{c}0.0585 \\
{[0.0418]}\end{array}$ & $\begin{array}{l}-0.0311 \\
{[0.0332]}\end{array}$ & $\begin{array}{l}0.0900+ \\
{[0.0502]}\end{array}$ & $\begin{array}{c}-0.0446 \\
{[0.0509]}\end{array}$ & $\begin{array}{l}-0.0397 \\
{[0.0645]}\end{array}$ & $\begin{array}{c}-0.0437 \\
{[0.0389]}\end{array}$ \\
\hline Have both children and grandchildren & $\begin{array}{c}0.0106^{*} \\
{[0.00532]}\end{array}$ & $\begin{array}{c}0.00214 \\
{[0.00857]}\end{array}$ & $\begin{array}{c}-1.98 \mathrm{e}-05 \\
{[0.0101]}\end{array}$ & $\begin{array}{c}0.00113 \\
{[0.0114]}\end{array}$ & $\begin{array}{c}-0.03+ \\
{[0.0165]}\end{array}$ & $\begin{array}{c}0.000584 \\
{[0.0207]}\end{array}$ & $\begin{array}{c}0.0154 \\
{[0.0150]}\end{array}$ \\
\hline \multicolumn{8}{|l|}{ F. Income $>$ Mean income $(\mathbf{N}=\mathbf{6 , 0 0 0})$} \\
\hline Have children but no grandchildren & $\begin{array}{c}0.000435 \\
{[0.00399]}\end{array}$ & $\begin{array}{c}0.00939 \\
{[0.00803]}\end{array}$ & $\begin{array}{c}-0.027 * * \\
{[0.00769]}\end{array}$ & $\begin{array}{c}-0.0198 * \\
{[0.00882]}\end{array}$ & $\begin{array}{l}0.00140 \\
{[0.0130]}\end{array}$ & $\begin{array}{c}0.0133 \\
{[0.0178]}\end{array}$ & $\begin{array}{l}0.0220+ \\
{[0.0122]}\end{array}$ \\
\hline Have grandchildren but no living children & $\begin{array}{c}0.0290 \\
{[0.0292]}\end{array}$ & $\begin{array}{c}0.0502 \\
{[0.0421]}\end{array}$ & $\begin{array}{l}-0.00821 \\
{[0.0399]}\end{array}$ & $\begin{array}{c}0.0490 \\
{[0.0453]}\end{array}$ & $\begin{array}{c}0.0809 \\
{[0.0617]}\end{array}$ & $\begin{array}{c}-0.132+ \\
{[0.0683]}\end{array}$ & $\begin{array}{c}-0.069 * * \\
{[0.0259]}\end{array}$ \\
\hline Have both children and grandchildren & $\begin{array}{c}0.00164 \\
{[0.00363]}\end{array}$ & $\begin{array}{c}0.00642 \\
{[0.00816]}\end{array}$ & $\begin{array}{c}-0.00827 \\
{[0.00827]}\end{array}$ & $\begin{array}{c}-0.0207^{*} \\
{[0.0101]}\end{array}$ & $\begin{array}{c}-0.0074 \\
{[0.0149]}\end{array}$ & $\begin{array}{c}-0.0124 \\
{[0.0197]}\end{array}$ & $\begin{array}{c}0.0407 * * \\
{[0.0135]}\end{array}$ \\
\hline \multicolumn{8}{|l|}{ G. $40<=$ Age $<60(N=6,699)$} \\
\hline Have children but no grandchildren & $\begin{array}{l}0.00709+ \\
{[0.00400]}\end{array}$ & $\begin{array}{c}0.00919 \\
{[0.00734]}\end{array}$ & $\begin{array}{c}-0.0159+ \\
{[0.00883]}\end{array}$ & $\begin{array}{c}-0.0170+ \\
{[0.00975]}\end{array}$ & $\begin{array}{c}-0.0005 \\
{[0.0131]}\end{array}$ & $\begin{array}{l}-0.00678 \\
{[0.0161]}\end{array}$ & $\begin{array}{c}0.0240 * \\
{[0.00977]}\end{array}$ \\
\hline Have grandchildren but no living children & $\begin{array}{c}0.00859 \\
{[0.0206]}\end{array}$ & $\begin{array}{c}0.0341 \\
{[0.0372]}\end{array}$ & $\begin{array}{c}0.000515 \\
{[0.0383]}\end{array}$ & $\begin{array}{l}0.0977+ \\
{[0.0572]}\end{array}$ & $\begin{array}{c}0.0604 \\
{[0.0639]}\end{array}$ & $\begin{array}{c}-0.136^{*} \\
{[0.0661]}\end{array}$ & $\begin{array}{c}-0.066^{* *} \\
{[0.0206]}\end{array}$ \\
\hline Have both children and grandchildren & $\begin{array}{c}0.0101 * \\
{[0.00454]}\end{array}$ & $\begin{array}{c}0.0130 \\
{[0.00847]}\end{array}$ & $\begin{array}{l}-0.00876 \\
{[0.0102]}\end{array}$ & $\begin{array}{l}-0.00427 \\
{[0.0118]}\end{array}$ & $\begin{array}{c}-0.0248 \\
{[0.0152]}\end{array}$ & $\begin{array}{l}-0.0268 \\
{[0.0187]}\end{array}$ & $\begin{array}{c}0.0416^{* *} \\
{[0.0121]}\end{array}$ \\
\hline \multicolumn{8}{|l|}{ H. Age>60 $(\mathrm{N}=5,150)$} \\
\hline Have children but no grandchildren & $\begin{array}{c}-0.00875 \\
{[0.00616]}\end{array}$ & $\begin{array}{c}0.00496 \\
{[0.0108]}\end{array}$ & $\begin{array}{c}-0.00770 \\
{[0.0103]}\end{array}$ & $\begin{array}{l}-0.00458 \\
{[0.0124]}\end{array}$ & $\begin{array}{l}0.00932 \\
{[0.0184]}\end{array}$ & $\begin{array}{l}0.0464+ \\
{[0.0270]}\end{array}$ & $\begin{array}{c}-0.0396+ \\
{[0.0213]}\end{array}$ \\
\hline Have grandchildren but no living children & $\begin{array}{c}0.0120 \\
{[0.0229]}\end{array}$ & $\begin{array}{c}0.0442 \\
{[0.0378]}\end{array}$ & $\begin{array}{c}-0.0378 \\
{[0.0341]}\end{array}$ & $\begin{array}{c}0.0497 \\
{[0.0345]}\end{array}$ & $\begin{array}{c}0.0195 \\
{[0.0451]}\end{array}$ & $\begin{array}{l}-0.00871 \\
{[0.0624]}\end{array}$ & $\begin{array}{r}-0.0787+ \\
{[0.0413]}\end{array}$ \\
\hline Have both children and grandchildren & $\begin{array}{c}-0.00914 \\
{[0.00727]}\end{array}$ & $\begin{array}{l}-0.00535 \\
{[0.00922]}\end{array}$ & $\begin{array}{c}-0.00273 \\
{[0.00904]}\end{array}$ & $\begin{array}{c}-0.0149 \\
{[0.0117]}\end{array}$ & $\begin{array}{c}0.0132 \\
{[0.0159]}\end{array}$ & $\begin{array}{c}0.0346 \\
{[0.0237]}\end{array}$ & $\begin{array}{c}-0.0157 \\
{[0.0195]}\end{array}$ \\
\hline
\end{tabular}


Table A1: Descriptive Statistics

\begin{tabular}{|c|c|c|c|c|c|c|c|c|}
\hline & \multicolumn{3}{|l|}{$\begin{array}{c}\text { Full } \\
\text { sample }\end{array}$} & \multicolumn{4}{|c|}{ Life satisfaction level } & \multirow[b]{2}{*}{7} \\
\hline & Mean & 1 & 2 & 3 & 4 & 5 & 6 & \\
\hline Life satisfaction & 5.31 & & & & & & & \\
\hline Have children but no grandchildren & 0.21 & 0.22 & 0.23 & 0.21 & 0.20 & 0.22 & 0.22 & 0.19 \\
\hline Have grandchildren but no (alive) children & 0.01 & 0.01 & 0.02 & 0.01 & 0.02 & 0.01 & 0.01 & 0.01 \\
\hline Have both children and grandchildren & 0.41 & 0.47 & 0.37 & 0.34 & 0.36 & 0.36 & 0.42 & 0.55 \\
\hline \multicolumn{9}{|l|}{ Control variables } \\
\hline Age & 58.11 & 58.30 & 55.33 & 54.08 & 55.68 & 56.40 & 58.42 & 62.67 \\
\hline Men & 0.43 & 0.49 & 0.43 & 0.46 & 0.46 & 0.45 & 0.45 & 0.38 \\
\hline Years of education & 15.96 & 15.58 & 15.85 & 16.08 & 15.90 & 15.95 & 16.10 & 15.66 \\
\hline Log of household income & 7.76 & 7.47 & 7.64 & 7.63 & 7.67 & 7.77 & 7.86 & 7.65 \\
\hline Race: Mixed & 0.004 & 0.006 & 0.015 & 0.005 & 0.007 & 0.003 & 0.085 & 0.004 \\
\hline Race: Indian/Pakistani/Bangladeshi & 0.013 & 0.019 & 0.028 & 0.017 & 0.022 & 0.018 & 0.010 & 0.009 \\
\hline Race: Chinese \& Other Asians & 0.004 & 0.000 & 0.004 & 0.003 & 0.012 & 0.010 & 0.003 & 0.002 \\
\hline Race: Blacks & 0.012 & 0.016 & 0.012 & 0.014 & 0.021 & 0.019 & 0.010 & 0.007 \\
\hline Race: Other Groups & 0.006 & 0.010 & 0.011 & 0.008 & 0.006 & 0.010 & 0.004 & 0.005 \\
\hline Self-employed & 0.08 & 0.02 & 0.07 & 0.08 & 0.09 & 0.07 & 0.09 & 0.06 \\
\hline Unemployed & 0.04 & 0.05 & 0.09 & 0.09 & 0.06 & 0.04 & 0.02 & 0.03 \\
\hline Retired & 0.34 & 0.33 & 0.24 & 0.20 & 0.26 & 0.29 & 0.36 & 0.52 \\
\hline Married & 0.62 & 0.45 & 0.52 & 0.49 & 0.53 & 0.59 & 0.69 & 0.66 \\
\hline Separated & 0.03 & 0.08 & 0.06 & 0.06 & 0.05 & 0.03 & 0.03 & 0.02 \\
\hline Divorced & 0.13 & 0.19 & 0.17 & 0.22 & 0.17 & 0.16 & 0.11 & 0.10 \\
\hline Widowed & 0.09 & 0.16 & 0.09 & 0.07 & 0.10 & 0.09 & 0.09 & 0.14 \\
\hline$N$ & 11,942 & 309 & 540 & 782 & 1,043 & 1,864 & 5,524 & 1,880 \\
\hline
\end{tabular}


Table A2: Standard and Generalized Ordered Probit Estimates for the Control

Variables (Panel C, Table 1)

\begin{tabular}{|c|c|c|c|c|c|c|c|}
\hline $\begin{array}{l}\text { Dependent variable: } \\
\text { Life satisfaction }\end{array}$ & $\begin{array}{l}\text { OPROBIT } \\
\text { Overall }\end{array}$ & $\begin{array}{c}\text { GOPROBIT } \\
\theta_{1} \\
\end{array}$ & $\boldsymbol{\theta}_{2}$ & $\boldsymbol{\theta}_{3}$ & $\boldsymbol{\theta}_{4}$ & $\theta_{5}$ & $\theta_{6}$ \\
\hline Age & $\begin{array}{c}0.0325 * * \\
{[0.00817]}\end{array}$ & $\begin{array}{c}0.0170 \\
{[0.0225]}\end{array}$ & $\begin{array}{l}0.00802 \\
{[0.0149]}\end{array}$ & $\begin{array}{l}0.0252 * \\
{[0.0121]}\end{array}$ & $\begin{array}{c}0.0333 * * \\
{[0.0110]}\end{array}$ & $\begin{array}{l}0.0421 * * \\
{[0.00994]}\end{array}$ & $\begin{array}{c}0.0453 * * \\
{[0.0120]}\end{array}$ \\
\hline Age-squared/100 & $\begin{array}{c}-0.0163 * \\
{[0.00674]}\end{array}$ & $\begin{array}{l}-0.00926 \\
{[0.0183]}\end{array}$ & $\begin{array}{l}0.000412 \\
{[0.0120]}\end{array}$ & $\begin{array}{c}-0.0107 \\
{[0.00988]}\end{array}$ & $\begin{array}{c}-0.0147 \\
{[0.00899]}\end{array}$ & $\begin{array}{c}- \\
0.0217 * * \\
{[0.00814]}\end{array}$ & $\begin{array}{c}- \\
0.0275 * * \\
{[0.00941]}\end{array}$ \\
\hline Male & $\begin{array}{c}-0.108 * * \\
{[0.0205]}\end{array}$ & $\begin{array}{c}-0.160 * * \\
{[0.0578]}\end{array}$ & $\begin{array}{c}-0.0226 \\
{[0.0369]}\end{array}$ & $\begin{array}{c}-0.0478 \\
{[0.0316]}\end{array}$ & $\begin{array}{c}0.0796^{* *} \\
{[0.0282]}\end{array}$ & $\begin{array}{c}0.0820 * * \\
{[0.0256]}\end{array}$ & $\begin{array}{c}-0.177 * * \\
{[0.0308]}\end{array}$ \\
\hline Health: Good & $\begin{array}{c}-0.241 * * \\
{[0.0326]}\end{array}$ & $\begin{array}{c}0.193 * \\
{[0.0935]}\end{array}$ & $\begin{array}{c}0.0697 \\
{[0.0630]}\end{array}$ & $\begin{array}{c}-0.0140 \\
{[0.0534]}\end{array}$ & $\begin{array}{c}-0.151 * * \\
{[0.0472]}\end{array}$ & $\begin{array}{c}-0.226^{* *} \\
{[0.0405]}\end{array}$ & $\begin{array}{c}-0.393 * * \\
{[0.0419]}\end{array}$ \\
\hline Health: Fair & $\begin{array}{l}-0.458 * * \\
{[0.0331]}\end{array}$ & $\begin{array}{c}0.191^{*} \\
{[0.0944]}\end{array}$ & $\begin{array}{c}0.0614 \\
{[0.0645]}\end{array}$ & $\begin{array}{l}-0.164 * * \\
{[0.0526]}\end{array}$ & $\begin{array}{l}-0.434 * * \\
{[0.0462]}\end{array}$ & $\begin{array}{l}-0.537 * * \\
{[0.0405]}\end{array}$ & $\begin{array}{l}-0.599 * * \\
{[0.0437]}\end{array}$ \\
\hline Health: Poor & $\begin{array}{c}-0.762 * * \\
{[0.0379]}\end{array}$ & $\begin{array}{c}0.0452 \\
{[0.0982]}\end{array}$ & $\begin{array}{c}-0.129+ \\
{[0.0675]}\end{array}$ & $\begin{array}{c}-0.474 * * \\
{[0.0564]}\end{array}$ & $\begin{array}{c}-0.792 * * \\
{[0.0502]}\end{array}$ & $\begin{array}{c}-0.938 * * \\
{[0.0456]}\end{array}$ & $\begin{array}{c}-0.823 * * \\
{[0.0526]}\end{array}$ \\
\hline Health: Very poor & $\begin{array}{c}-1.217 * * \\
{[0.0523]}\end{array}$ & $\begin{array}{c}-0.492 * * \\
{[0.103]}\end{array}$ & $\begin{array}{c}-0.675 * * \\
{[0.0764]}\end{array}$ & $\begin{array}{c}-1.023 * * \\
{[0.0668]}\end{array}$ & $\begin{array}{c}-1.322^{* *} \\
{[0.0613]}\end{array}$ & $\begin{array}{c}-1.357 * * \\
{[0.0591]}\end{array}$ & $\begin{array}{c}-1.018 * * \\
{[0.0739]}\end{array}$ \\
\hline Log of household income & $\begin{array}{c}0.0501 * * \\
{[0.0152]}\end{array}$ & $\begin{array}{c}0.0266 \\
{[0.0415]}\end{array}$ & $\begin{array}{c}0.00633 \\
{[0.0288]}\end{array}$ & $\begin{array}{c}0.0959 * * \\
{[0.0220]}\end{array}$ & $\begin{array}{l}0.110 * * \\
{[0.0206]}\end{array}$ & $\begin{array}{c}0.100 * * \\
{[0.0184]}\end{array}$ & $\begin{array}{c}0.000914 \\
{[0.0208]}\end{array}$ \\
\hline Age left full-time education & $\begin{array}{c}-0.0227 * * \\
{[0.00855]}\end{array}$ & $\begin{array}{c}0.0603 * \\
{[0.0277]}\end{array}$ & $\begin{array}{c}0.0414 * \\
{[0.0173]}\end{array}$ & $\begin{array}{l}-0.00745 \\
{[0.0138]}\end{array}$ & $\begin{array}{c}0.00294 \\
{[0.0119]}\end{array}$ & $\begin{array}{c}0.0139 \\
{[0.0107]}\end{array}$ & $\begin{array}{c}0.1000 * * \\
{[0.0123]}\end{array}$ \\
\hline Self-employed & $\begin{array}{c}0.0236 \\
{[0.0368]}\end{array}$ & $\begin{array}{l}0.285+ \\
{[0.146]}\end{array}$ & $\begin{array}{c}0.0361 \\
{[0.0776]}\end{array}$ & $\begin{array}{l}-0.00323 \\
{[0.0606]}\end{array}$ & $\begin{array}{l}-0.0383 \\
{[0.0528]}\end{array}$ & $\begin{array}{c}0.0687 \\
{[0.0483]}\end{array}$ & $\begin{array}{l}-0.00266 \\
{[0.0615]}\end{array}$ \\
\hline Unemployed & $\begin{array}{c}-0.202 * * \\
{[0.0555]}\end{array}$ & $\begin{array}{l}-0.0302 \\
{[0.147]}\end{array}$ & $\begin{array}{c}-0.351 * * \\
{[0.0873]}\end{array}$ & $\begin{array}{c}-0.359 * * \\
{[0.0729]}\end{array}$ & $\begin{array}{c}-0.327 * * \\
{[0.0685]}\end{array}$ & $\begin{array}{c}-0.257 * * \\
{[0.0675]}\end{array}$ & $\begin{array}{c}0.0527 \\
{[0.0868]}\end{array}$ \\
\hline Retired & $\begin{array}{l}0.242 * * \\
{[0.0360]}\end{array}$ & $\begin{array}{l}-0.0110 \\
{[0.108]}\end{array}$ & $\begin{array}{c}0.0439 \\
{[0.0765]}\end{array}$ & $\begin{array}{c}0.186^{* *} \\
{[0.0580]}\end{array}$ & $\begin{array}{l}0.223 * * \\
{[0.0512]}\end{array}$ & $\begin{array}{c}0.299 * * \\
{[0.0441]}\end{array}$ & $\begin{array}{l}0.278 * * \\
{[0.0501]}\end{array}$ \\
\hline Married & $\begin{array}{l}0.140^{* *} \\
{[0.0349]}\end{array}$ & $\begin{array}{c}0.198^{*} \\
{[0.0956]}\end{array}$ & $\begin{array}{l}0.220 * * \\
{[0.0634]}\end{array}$ & $\begin{array}{l}0.183^{* *} \\
{[0.0516]}\end{array}$ & $\begin{array}{l}0.194 * * \\
{[0.0460]}\end{array}$ & $\begin{array}{l}0.218 * * \\
{[0.0434]}\end{array}$ & $\begin{array}{l}-0.00183 \\
{[0.0564]}\end{array}$ \\
\hline Separated & $\begin{array}{c}-0.196 * * \\
{[0.0648]}\end{array}$ & $\begin{array}{c}-0.273+ \\
{[0.145]}\end{array}$ & $\begin{array}{c}-0.127 \\
{[0.0998]}\end{array}$ & $\begin{array}{c}-0.250 * * \\
{[0.0859]}\end{array}$ & $\begin{array}{c}-0.233 * * \\
{[0.0789]}\end{array}$ & $\begin{array}{c}-0.0747 \\
{[0.0776]}\end{array}$ & $\begin{array}{c}-0.264 * \\
{[0.104]}\end{array}$ \\
\hline Divorced & $\begin{array}{l}-0.0847 * \\
{[0.0419]}\end{array}$ & $\begin{array}{l}0.0573 \\
{[0.108]}\end{array}$ & $\begin{array}{c}0.0835 \\
{[0.0722]}\end{array}$ & $\begin{array}{l}-0.0563 \\
{[0.0602]}\end{array}$ & $\begin{array}{l}-0.0651 \\
{[0.0545]}\end{array}$ & $\begin{array}{l}-0.0916+ \\
{[0.0520]}\end{array}$ & $\begin{array}{l}-0.132+ \\
{[0.0678]}\end{array}$ \\
\hline Widowed & $\begin{array}{c}-0.0685 \\
{[0.0512]}\end{array}$ & $\begin{array}{c}-0.135 \\
{[0.127]}\end{array}$ & $\begin{array}{c}-0.0245 \\
{[0.0856]}\end{array}$ & $\begin{array}{c}-0.0201 \\
{[0.0719]}\end{array}$ & $\begin{array}{c}-0.0609 \\
{[0.0653]}\end{array}$ & $\begin{array}{c}-0.0331 \\
{[0.0604]}\end{array}$ & $\begin{array}{c}-0.0984 \\
{[0.0715]}\end{array}$ \\
\hline Race: Mixed & $\begin{array}{c}-0.181 \\
{[0.163]}\end{array}$ & $\begin{array}{c}-0.184 \\
{[0.350]}\end{array}$ & $\begin{array}{l}-0.526^{*} \\
{[0.210]}\end{array}$ & $\begin{array}{l}-0.458^{*} \\
{[0.200]}\end{array}$ & $\begin{array}{c}-0.494 * * \\
{[0.180]}\end{array}$ & $\begin{array}{l}-0.258 \\
{[0.180]}\end{array}$ & $\begin{array}{c}0.216 \\
{[0.217]}\end{array}$ \\
\hline Race: & & & & & & & \\
\hline Indian/Pakistani/Bangladeshi & $\begin{array}{l}-0.231 * * \\
{[0.0884]}\end{array}$ & $\begin{array}{l}-0.229 \\
{[0.208]}\end{array}$ & $\begin{array}{l}-0.329 * \\
{[0.148]}\end{array}$ & $\begin{array}{l}-0.246+ \\
{[0.129]}\end{array}$ & $\begin{array}{l}-0.245^{*} \\
{[0.107]}\end{array}$ & $\begin{array}{c}-0.364 * * \\
{[0.109]}\end{array}$ & $\begin{array}{l}0.0544 \\
{[0.145]}\end{array}$ \\
\hline Race: Chinese \& Other Asians & $\begin{array}{l}-0.109 \\
{[0.114]}\end{array}$ & $\begin{array}{c}3.627 * * \\
{[0.167]}\end{array}$ & $\begin{array}{c}0.141 \\
{[0.377]}\end{array}$ & $\begin{array}{l}0.523 * \\
{[0.249]}\end{array}$ & $\begin{array}{l}-0.0508 \\
{[0.202]}\end{array}$ & $\begin{array}{c}-0.508 * * \\
{[0.180]}\end{array}$ & $\begin{array}{l}-0.0323 \\
{[0.291]}\end{array}$ \\
\hline
\end{tabular}




\begin{tabular}{|c|c|c|c|c|c|c|c|}
\hline Race: Blacks & $\begin{array}{l}-0.0161 \\
{[0.0848]}\end{array}$ & $\begin{array}{c}-0.217 \\
{[0.235]}\end{array}$ & $\begin{array}{l}0.0966 \\
{[0.147]}\end{array}$ & $\begin{array}{c}0.180 \\
{[0.137]}\end{array}$ & $\begin{array}{l}0.0426 \\
{[0.118]}\end{array}$ & $\begin{array}{l}-0.119 \\
{[0.109]}\end{array}$ & $\begin{array}{c}0.0778 \\
{[0.158]}\end{array}$ \\
\hline Race: Other ethnic groups & $\begin{array}{c}-0.0867 \\
{[0.137]}\end{array}$ & $\begin{array}{c}-0.345 \\
{[0.289]}\end{array}$ & $\begin{array}{c}-0.302 \\
{[0.201]}\end{array}$ & $\begin{array}{l}-0.0551 \\
{[0.174]}\end{array}$ & $\begin{array}{l}-0.0263 \\
{[0.167]}\end{array}$ & $\begin{array}{c}-0.184 \\
{[0.160]}\end{array}$ & $\begin{array}{l}0.0463 \\
{[0.204]}\end{array}$ \\
\hline Cut_1 & $\begin{array}{c}-1.186 * * \\
{[0.296]}\end{array}$ & & & & & & \\
\hline Cut_2 & $\begin{array}{c}-0.668 * \\
{[0.296]}\end{array}$ & & & & & & \\
\hline Cut_3 & $\begin{array}{c}-0.256 \\
{[0.295]}\end{array}$ & & & & & & \\
\hline Cut_4 & $\begin{array}{c}0.123 \\
{[0.296]}\end{array}$ & & & & & & \\
\hline Cut_5 & $\begin{array}{l}0.637^{*} \\
{[0.296]}\end{array}$ & & & & & & \\
\hline Cut_6 & $\begin{array}{c}2.073 * * \\
{[0.297]}\end{array}$ & & & & & & \\
\hline Constant & & 0.460 & 0.490 & -0.342 & $-1.142 * *$ & $-2.019 * *$ & -0.680 \\
\hline Observations & 11,849 & 11,849 & 11,849 & 11,849 & 11,849 & 11,849 & 11,849 \\
\hline
\end{tabular}

Note: All regressions include regional dummies. Robust standard errors are in parentheses. $+<10 \%$; $*<5 \%$;

$* *<1 \%$. 